\title{
HUBUNGAN ANTARA PENGETAHUAN DAN SIKAP IBU NIFAS DENGAN PEMBERIAN KOLOSTRUM PADA BAYI BARU LAHIR DI RSKD IBU DAN ANAK PERTIWI MAKASSAR
}

\author{
Mardiana Mustafa, Suhartatik \\ Poltekkes Kemenkes Makassar \\ mardianamustafa@poltekkes-mks.ac.id \\ tatiek@poltekkes-mks.ac.id
}

\begin{abstract}
Breastmilk (breast milk) is the best natural nutrient for babies because it contains the energy needs and substances needed during the first six months of life. Breast milk composition is not the same from time to time. Breast milk composition is influenced by several factors including lactation stage, nutritional status and maternal nutrition. According to the stages of lactation, breast milk is divided into colostrum, transitional / transitional breastfeeding, and mature breast milk. Colostrum is a thick yellow milk produced from the first day after the mother gives birth. Colostrum is also known as gold fluid that is yellow or can also clear and more like blood than milk, because it contains living cells resembling white blood cells that can kill germs, therefore colostrum should be given to the baby. This study aims to know the relationship between knowledge and postpartum attitude with the provision of colostrum in newborns in RSKD Ibu and Anak Pertiwi Makassar. The method used in this research is observational analytic with Cross Sectional approach. This research was conducted from October to December with the sample of 89 respondents. Data collection was done by division of questionnaire and processed by using statistical test Chi-Square with significance level $\alpha=0,05$. The result of statistical test obtained in this research is $p=0,014$ for knowledge variable and $p=0,015$ for attitude variable, where $p<$ from $\alpha$ value. So it can be concluded that there is a significant relationship between knowledge and postpartum attitude with the provision of colostrum in newborns in RSKD Mother and Child Pertiwi Makassar.
\end{abstract}

Keywords: knowledge, attitude and giving of colostrum.

\begin{abstract}
ABSTRAK
Air susu ibu (ASI) merupakan nutrisi alamiah terbaik bagi bayi karena mengandung kebutuhan energi dan zat yang dibutuhkan selama enam bulan pertama kehidupan bayi. Komposisi ASI tidak sama dari waktu ke waktu. Komposisi ASI dipengaruhi oleh beberapa faktor diantaranya stadium laktasi, status gizi dan asupan nutrisi ibu. Menurut stadium laktasi, ASI terbagi menjadi kolostrum, ASI transisi/ peralihan, dan ASI matur. Kolostrum merupakan ASI kental berwarna kuning yang dihasilkan sejak hari pertama setelah ibu melahirkan. Kolostrum juga dikenal dengan cairan emas yang berwarna kuning atau dapat pula jernih dan lebih menyerupai darah daripada susu, sebab mengandung sel hidup menyerupai sel darah putih yang dapat membunuh kuman penyakit, oleh karena itu kolostrum harus diberikan kepada bayi. Penelitian ini bertujuan untuk diketahuinya
\end{abstract}


hubungan antara pengetahuan dan sikap ibu nifas dengan pemberian kolostrum pada bayi baru lahir di RSKD Ibu dan Anak Pertiwi Makassar. Metode yang digunakan dalam penelitian ini adalah observasional analitik dengan pendekatan Cross Sectional. Penelitian ini dilakukan mulai bulan Oktober-Desember dengan jumlah sampel 89 responden. Pengumpulan data dilakukan dengan pembagian kuesioner dan diolah dengan menggunakan uji statistic $C h i$-Square dengan tingkat kemaknaan $\alpha=0,05$. Hasil uji statistik yang diperoleh dalam penelitian ini adalah $\mathrm{p}=0,014$ untuk variabel pengetahuan dan $\mathrm{p}=0,015$ untuk variabel sikap, dimana $\mathrm{p}<$ dari nilai $\alpha$. Sehingga dapat disimpulkan bahwa ada hubungan yang bermakna antara pengetahuan dan sikap ibu nifas dengan pemberian kolostrum pada bayi baru lahir di RSKD Ibu dan Anak Pertiwi Makassar.

Kata Kunci: pengetahuan, sikap dan pemberian kolostrum.

\section{PENDAHULUAN}

Air susu ibu merupakan nutrisi alamaia terbaik bagi bayi karena mengandung kebutuhan energi dan zat yang dibutuhkan selama enam bulan pertama. ASI tidak hanya bergizi, tetapi juga membantu melindungi bayi dari hampir semua jenis infeksi, dengan meningkatkan daya tahan tubuhnya. Menurut stadium laktasi, ASI terbagi menjadi kolostrum, ASI transisi dan ASI matur. Kolostrum merupakan ASI kental berwarna kuning yang dihasilkan sejak hari pertama setelah ibu melahirkan. Volume kolostrum berkisar antara 2-20 $\mathrm{ml}$ dalam 3 hari dengan rata-rata energi yang dapat diperoleh dari $100 \mathrm{ml}$ kolostrum adalah 67 kalori.

Menurut data dari world Health organization (WHO), ada 170 juta anak mengalami kurang gizi diseluruh dunia.
Sebanyak 3 juta diantaranya meninggal tiap tahun akibat kurang gizi. Angka kematian yang cukup tinggi didunia sebenarnya dapat dihindari dengan poemberian air susu ibu (ASI).

Penyebab umum kegagalan pemberian ASI ekslusif adalah minimnya pengetahuan ibu tentang ASI eksklusif dan menyusui, ibu yang bekerja, tidak ada dukungan dari keluarga, teknik menyusui yang tidak tepat dan mitos ASI encer tidak tepat bagi bayi. Di Indonesia pada tahun 2007, angka kematian bayi adalah 35 per 1000 kelahiran hidup. Oleh karena itu, organisasi kesehatan dunia merekomendasikan semua bayi perlu mendapat kolostrum untuk melawan infeksi dan ASI eksklusif selama 6 bulan untuk menjamin kecukupan gizi bayi.

Sedangkan menurut dirjen bina kesehatan masyarakat 2003 menyatakan bahwa 
pemberian ASI pada 30 menit pertama bayi baru lahir hanya $8,3 \%, 4,36 \%$ pada satu jam pertama bayi baru lahir, 3,7 \% bayi memperoleh ASI pada hari pertama.

Dalam riskesdas 2013, dikumpulkan data tentang pola pemberian ASI dan makanan pendamping ASI (MP-ASI) dari umur 023 bulan yang meliputi proses mulai menyusu, inisiasi menyusui dini (IMD), pemberian MP-ASI. Presentase nasional menyusu kurang dari 1 jam (IMD) setelah bayi baru lahir adalah 34,4 \% dengan presentase tertinggi di Nusa Tenggara Barat (52,9\%) dan terendah di Papua Barat (21,7\%).

Berdasrkan data yang diperoleh dari rekam medic RSKD Pertiwi Makassar jumlah ibu post partum pada tahun 2015 adalah 317 orang yang memberikan kolosrtrum pada bayi baru lahir adalah sebanyak 186 orang dan yang tidak memberikan kolostrum pada bayi baru lahir adalah sebanyak 130 orang. Oleh karena itu penulis tertarik untuk melakukan penelitian apakah ada hubungan antara pengetahuan dan sikap ibu nifas dengan pemberian kolostrum pada bayi baru lahir di RSKD Ibu Dan Anak Pertiwi Makassar.

\section{METODE}

Lokasi, Populasi, Dan Sampel

Penelitian ini menggunakan menggunakan metode penelitian observasional analitik dengan menggunakan pendekatan cross sectional yaitu jenis penelitianyang menekankan pada waktu pengukuran/ observasi data dan variabel independendan variabel devendenhanya satu kali pada satu saat.

Penelitian ini dilaksanakan di RSKD Ibu dan Anak Pertiwi Makassar dan telah dilaksanakan mulai bulan oktober sampai desember. Populasi dalam penelitian adalah seluruh ibu nifas dan menyusui di RSKD Ibu Dan Anak Pertiwi Makassar sebanyak 317 orang. Dengan jumlah sampel 89 responden. Teknik pengambilan sampel dilakukan dengan teknik simple random sampling yaitu cara pengambilan sampel dilakukan secara acak, cara ini dipakai jika populasi dianggap homogen (Setiadi, 2013) adapun kriteria inklusi dan eksklusi dalam penelitian ini adalah :

1. Kriteria Inklusi

a. Ibu nifas di RSKD Ibu dan Anak Pertiwi Makassar 
b. Ibu nifas yang memberikan ASI di RSKD Ibu dan Anak Pertiwi Makassar

c. Bisa baca dan tulis

d. Bisa berkomunikasi dengan baik

2. Kriteria Eksklusi

a. Ibu nifas yang menjalani perawatan diruang nifas tetapi menolak untuk diteliti

b. Ibu nifas yang menjalani perawatan lebih dari 4 hari

\section{HASIL}

1. Analisis Univariat

Tabel 1. distribusi frekuensi ibu nifas berdasarkan umur di RSKD Ibu dan Anak Pertiwi Makassar tahun 2015

\begin{tabular}{|c|c|c|}
\hline Umur & $\mathrm{n}$ & $\%$ \\
\hline $18-25$ & 29 & $32,6 \%$ \\
\hline $26-35$ & 48 & $53,9 \%$ \\
\hline $36-45$ & 12 & $13,5 \%$ \\
\hline Total & 89 & $100 \%$ \\
\hline
\end{tabular}

Berdasarkan tabel 1 diketahui

bahwa dari 89 responden , terdapat 29 responden $(32,6 \%)$ yang berumur 18 25,48 responden $(53,9 \%)$ yang berumur 26-35, dan 12 responden $(13,5 \%)$ yang berumur 36-45 tahun.
Tabel 2. Distribusi Frekuensi Ibu Nifas Berdasarkan Pekerjaan di RSKD Ibu dan Anak Pertiwi Makassar Tahun 2015

\begin{tabular}{|l|c|c|}
\hline Pekerjaan & $\mathrm{n}$ & $\%$ \\
\hline IRT & 60 & $67,4 \%$ \\
\hline PNS & 19 & $23,1 \%$ \\
\hline Wiraswasta & 8 & $9 \%$ \\
\hline Honorer & 2 & $2,2 \%$ \\
\hline Total & 89 & $100 \%$ \\
\hline
\end{tabular}

Berdasarkan Tabel 5.2, dari 89 responden menunjukkan bahwa mayoritas pekerjaan responden adalah IRT sebanyak 60 responden atau 67,4\%, PNS sebanyak 19 responden atau $23,1 \%$, wiraswasta sebanyak 8 responden atau 9\% dan honorer sebanyak 2 responden atau 2,2 \%.

Tabel 3 .Distribusi Frekuensi Ibu Nifas Berdasarkan Pendidikan Di RSKD Ibu dan Anak Pertiwi Makassar Tahun 2015

\begin{tabular}{|c|c|c|}
\hline Pendidikan & $\mathrm{n}$ & $\%$ \\
\hline SMP & 5 & $5,6 \%$ \\
\hline SMA & 51 & $57,3 \%$ \\
\hline D3 & 9 & $10,1 \%$ \\
\hline S1 & 24 & $27 \%$ \\
\hline
\end{tabular}

Tabel 3 menunjukkan bahwa sebagian besar tingkat pendidikan dari 
89 responden adalah SMA yakni sebanyak 51 responden atau 57,3\%, S1 sebanyak 21 responden atau $27 \%$, D3 sebanyak 9 responden atau $10,1 \%$, dan SMP sebanyak 5 responden atau $5,6 \%$.

Tabel 4 Distribusi Frekuensi Ibu Nifas Berdasarkan Pengetahuan di RSKD Ibu dan Anak Pertiwi Makassar Tahun 2015

\begin{tabular}{|c|c|c|}
\hline Pengetahuan & $\mathrm{n}$ & $\%$ \\
\hline Baik & 77 & $86,5 \%$ \\
\hline Kurang & 12 & $13,5 \%$ \\
\hline Total & 89 & $100 \%$ \\
\hline
\end{tabular}

Berdasarkan tabel 4, dari 89 responden menunjukkan bahwa sebanyak 12 responden atau 13,5\% yang memiliki pengetahuan kurang dan yang memiliki pengetahuan baik sebanyak 77 responden atau $86,5 \%$.

Table 5 Distribusi Frekuensi Ibu Nifas Berdasarkan Sikap di RSKD Ibu dan Anak Pertiwi Makassar Tahun 2015.

\begin{tabular}{|c|c|c|}
\hline Sikap & $\mathrm{n}$ & $\%$ \\
\hline Baik & 84 & $94,4 \%$ \\
\hline Kurang & 5 & $5,6 \%$ \\
\hline Total & 89 & $100 \%$ \\
\hline
\end{tabular}

Berdasarkan tabel 5 menunjukkan bahwa dari 89 responden yang memiliki sikap positif sebanyak 84 responden atau 94,4\% dan yang memiliki sikap negatif adalah sebanyak 5 responden atau $5,6 \%$.

2. Analisa bivariat

Tabel 6 hubungan antara pengetahuan dengan pemberian kolostrum pada bayi baru lahir di RSKD Ibu dan Anak Pertiwi Makassar Tahun 2015.

\begin{tabular}{|c|c|c|c|c|c|c|}
\hline \multirow{2}{*}{$\begin{array}{c}\text { Penget } \\
\text { ahuan }\end{array}$} & \multicolumn{4}{|c|}{$\begin{array}{c}\text { Pemberian } \\
\text { Kolostrum }\end{array}$} & \multicolumn{2}{c|}{ Total } \\
\cline { 2 - 6 } & \multicolumn{2}{|c|}{ Ya } & \multicolumn{2}{|c|}{ Tidak } & \multirow{2}{*}{$\%$} \\
\cline { 2 - 6 } & $\mathrm{n}$ & $\%$ & $\mathrm{n}$ & $\%$ & & \\
\hline Baik & 75 & 84,3 & 2 & 2,2 & 77 & 86,5 \\
\hline Kurang & 9 & 10,1 & 3 & 3,4 & 12 & 13,5 \\
\hline Total & 84 & 94,4 & 5 & 5,6 & 89 & 100 \\
\hline \multicolumn{4}{|c|}{$p=0,014$} \\
\hline
\end{tabular}

Dari tabel 6, dapat diketahui bahwa dari total 89 responden (100 $\%)$, sebanyak 77 responden (100\%) yang berpengetahuan baik, 75 responden $(86,5 \%)$ memberikan kolostrum dan 2 responden $(2,2 \%)$ tidak memberikan kolostrum pada bayinya. Sedangkan sebanyak 12 responden (100\%) yang berpengetahuan kurang, 9 responden 
$(10,1 \%)$ yang memberikan kolostrum dan 3 responden $(3,4 \%)$ yang tidak memberikan kolostrum.

Tabel 7 hubungan antara sikap ibu nifas dengan pemberian kolostrum di RSKD Ibu Dan Anak Pertiwi Makassar Tahun 2015

\begin{tabular}{|c|c|c|c|c|c|c|}
\hline Sikap & \multicolumn{4}{|c|}{$\begin{array}{l}\text { Pemberian } \\
\text { Kolostrum }\end{array}$} & \multirow{2}{*}{ Total } \\
& \multicolumn{2}{|c|}{ Ya } & \multicolumn{2}{c|}{ Tidak } & \multicolumn{2}{c|}{} \\
\cline { 2 - 6 } & $\mathrm{n}$ & $\%$ & $\mathrm{n}$ & $\%$ & $\mathrm{n}$ & $\%$ \\
\hline Positif & 81 & 91,0 & 3 & 3,4 & 84 & 94,4 \\
\hline Negatif & 3 & 3,4 & 2 & 2,2 & 5 & 5,6 \\
\hline Total & 84 & 94,4 & 5 & 5,6 & 89 & 100 \\
\hline \multicolumn{7}{|c|}{$p=0,015$} \\
\hline
\end{tabular}

Dari tabel 7 di atas, dapat diketahui bahwa dari 89 responden, sebanyak 84 responden $(100 \%)$ yang memiliki sikap positif, sebanyak 81 responden $(90,0 \%)$ yang memberikan kolostrum, dan sebanyak 3 responden $(3,4 \%)$ yang tidak memberikan kolostrum. Sedangkan yang memiliki sikap negatif sebanyak 5 responden (100\%), yang memberikan kolostrum sebanyak 3 responden $(3,4 \%)$, dan yang tidak memberikan kolostrum sebanyak 2 responden $(2,2 \%)$.

\section{PEMBAHASAN}

1. Hubungan pengetahuan ibu nifas dengan pemberian kolostrum pada bayi baru lahir di RSKD Ibu dan Anak Pertiwi Makassar.

Pengetahuan merupakan hasil tahu dan ini terjadi setelah orang mengadakan penginderaan terhadap suatu objek tertentu. Pengetahuan itu sendiri dipengaruhi oleh oleh faktor pendidikan formal. Pengetahuan sangat erat hubungannya dengan pendidikan, dimana diharapkan bahwa dengan pendidikan yang tinggi maka orang tersebut akan semakin luas pula pengetahuannya. Akan tetapi perlu ditekankan, bukan berarti seseorang yang berpendidikan rendah mutlak berpengetahuan rendah pula (Wawan dan Dewi, 2011).

Hasil penelitian menunjukkan bahwa sebagian besar responden memiliki pengetahuan yang baik yaitu sebanyak 77 responden $(86,5 \%), 12$ responden memiliki pengetahuan kurang, $9(10,1 \%) \quad$ responden diantaranya memberikan kolostrum dan 3 responden $(3,4 \%)$ tidak memberikan kolostrum. 
Dan setelah dilakukan uji ChiSquare diperoleh nilai $\mathrm{p}=0.014$ yang berarti $\mathrm{p}<0.05$ sehingga $\mathrm{Ha}$ diterima dan Ho ditolak. Artinya ada hubungan antara pengetahuan ibu nifas dengan pemberian kolostrum pada bayi baru lahir di RSKD Ibu dan Anak Pertiwi Makassar.

Penelitian ini sejalan dengan adanya hasil penelitian yang dilakukan oleh Hemikeyanti di RSIA Siti Fatimah Makassar tentang hubungan tingkat pengetahuan dan pendidikan ibu terhadap pemberian kolostrum pada bayi baru lahir dengan hasil uji statistik $\mathrm{p}=0,001$,nilai $\mathrm{p}<$ dari $\alpha$ yang menunjukkan bahwa ada hubungan yang bermakna antara pengetahuan terhadap pemberian kolostrum pada bayi baru lahir dengan hasil.

Namun perlu ditekankan bahwa seseorang yang berpengetahuan baik belum tentu mengaplikasikan pemberian kolostrum pada bayi baru lahir dengan baik pula. Hal ini dapat dilihat dari hasil penenlitian dimana terdapat 2 responden $(2,2 \%)$ yang tidak memberikan kolostrum pada bayi yang baru lahir yang kemungkinan besar disebabkan oleh beberapa faktor seperti puting susu lecet yang menyebabkan rasa nyeri sehingga ibu merasa tidak nyaman untuk menyusui, kurangnya produksi ASI ataupun kurangnya pengalaman terutama pada ibu primipara.

Sehingga dapat disimpulkan bahwa pengetahuan seorang ibu nifas tentang pemberian kolostrum tidak hanya dilihat dari tingkat pendidikannya meskipun pengetahuan itu sendiri sangat erat kaitannya dengan pendidikan namun hal tersebut juga bisa dilihat dari beberapa faktor diantaranya informasi atau media massa, sosial budaya dan ekonomi, lingkungan, pengalaman dan usia.

2. Hubungan sikap ibu nifas dengan pemberian kolostrum pada bayi baru lahir.

Sikap merupakan respon tertutup seseorang terhadap stimulus atau objek tertentu yang sudah melibatkan faktor pendapat dan emosi yang bersangkutan (Notoatmodjo, 2010).

Hasil penelitian menunjukkan bahwa sebagian besar responden memiliki sikap positif terhadap pemberian kolostrum yaitu sebanyak 84 responden $(94,4 \%)$ yang 
memberikan kolostrum sebanyak 81 responden $(91,0 \%)$ dan yang tidak memberikan kolostrum sebanyak 3 responden $(3,4 \%)$. Sedangkan 5 responden $(5,6 \%)$ memiliki sikap negatif, sebanyak 3 responden $(3,4 \%)$ memberikan kolostrum dan 2 responden $(2,2 \%)$ tidak memberikan kolostrum.

Berdasarkan uji statistik, diperoleh nilai $\mathrm{p}=0,015$ yang berarti kurang dari $\alpha=0,05$. Dengan demikian Ha diterima dan Ho ditolak. Sehingga dapat disimpulkan bahwa ada hubungan antara sikap ibu nifas dengan pemberian kolostrum pada bayi baru lahir.

Penelitian ini juga sejalan dengan adanya penelitian yang dilakukan oleh Papona tentang hubungan pengetahuan dan sikap ibu nifas tentang pemberian kolostrum pada bayi baru lahir dimana dari 20 responden, $65 \%$ bersikap baik, dan $35 \%$ bersikap tidak baik, dimana perhitungan statistik menghasilkan $\mathrm{p}=0,005$ pada level 0,1 dan nilai korelasi spherman rho 0,601 menunjukkan bahwa korelasi positif dengan kekuatan korelasi kuat.

\section{KESIMPULAN}

Setelah dilakukan penelitian dan uji statistik, dengan tingkat kepercayaan 95\%, maka diperoleh kesimpulan sebagai berikut:

1. Adanya hubungan yang bermakna antara pengetahuan dan sikap ibu nifas dengan pemberian kolostrum pada bayi baru lahir di RSKD Ibu dan Anak Pertiwi Makassar.

2. Adanya hubungan yang bermakna antara sikap ibu nifas dengan pemberian kolostrum pada bayi baru lahir di RSKD Ibu dan Anak Pertiwi Makassar .

\section{SARAN}

Setelah melakukan penelitian, adapun saran yang dapat disampaikan dalam penelitian ini demi penyempurnaan penelitian selanjutnya antara lain:

1. Melihat pentingnya pemberian kolostrum pada bayi baru lahir, maka diharapkan agar petugas kesehatan lebih meningkatkan kolostrum atau ASI pertama yang lebih difokuskan kepada ibu nifas. 
2. Bagi peneliti

Dapat mengembangkan penelitian lebih lanjut lagi dengan menambah variabel-variabel lainnya selain pengetahuan dan sikap, serta lebih memahami tentang uji statistik yang digunakan.

\section{UCAPAN TERIMA KASIH}

Penulis mengucapkan terima kasih kepada semua yang telah membantu dalam proses penelitian ini.

\section{DAFTAR PUSTAKA}

Astutik, Reni Yuli. 2015. Asuhan Masa Nifas Dan Menyusui. CV Trans Info Media : Jakarta.

Fikawati, Sandra, dkk, 2015. Gizi Ibu dan Bayi. Raja Grafindo Persada : Jakarta

Hernikeyanti. 2014. Hubungan Tingkat Pengetahuan dan Pendidikan Ibu Terhadap Pemberian Kolostrum Pada Bayi Baru Lahir di RSIA Siti Fatimah Makassar.http://www.library.stikesnc.ac.id/files/disk1/6/e.pdf, diakses pada tanggal 20 januari 2016 jam 00.29 (online)

Hidayat, Aziz Azimul. 2012. Riset Keperawatan Dan Teknik Penulisan Ilmiah. Salemba Medika: Jakarta.

Maryunani, Anik. 2012. Inisiasi Menyusui Dini, Asi Eksklusif, dan Manajemen Laktasi. Trans Info Media : Jakarta.

Notoatmodjo, Soekidjo. 2010. Promosi Kesehatan Teori Dan Aplikasi. Rineka Cipta : Jakarta.

Notoatmodjo, Soekidjo. 2012. Metode Penelitian Kesehatan. Rineka Cipta : Jakarta

Nursalam. 2014. Metodologi Penelitian Ilmu Keperawatan. Salemba Medika: Jakarta.

Papona, Novita.,Laoh, Joice., Palandeng, Hendry.2013. Hubungan Pengetahuan Dan Sikap Ibu Nifas Tentang Pemberian Kolostrum Pada Bayi Baru Lahir Di Puskemas Ulu Kecamatan Siau Timur Kabupaten Kepulauan Sitaro. e-journal Keperawatan (e-Kp) Volume 1, Nomor 1. http://www.digilib.unimus.ac.id. diakses pada tanggal. 09 Oktober 2015, 11:41:2

Proverawati, Atika. 2010. ASI Dan Menyusui. Nuha Medika : Yogyakarta. 
Riyanto, Agus, Budiman .2013. Kapita Selekta Kuesioner Pengetahuan Dan Sikap Dalam Penelitian Kesehatan. Salemba Medika: Jakarta.

Riset

$$
\text { Kesehatan }
$$

Dasar

(Riskesdas).2013.http://depkes.go.id/resources/download/general/Hasil\%20Riskesda s\%202013.pdf, diakses pada tanggal 21 September 2015 jam 7.37 PM (online)

Sari, Eka Puspita. 2014. Asuhan Kebidanan Masa Nifas (Postnatal Care). CV Trans Info Media : Jakarta. 